\title{
IN SEARCH OF BUDDHIST VIRTUE: A CASE FOR A PLURALIST-GRADUALIST MORAL PHILOSOPHY
}

\author{
OREN HANNER
}

\begin{abstract}
Classical presentations of the Buddhist path prescribe the cultivation of various good qualities that are necessary for spiritual progress, from mindfulness (sati) and loving-kindness (metta) to faith (saddhā) and wisdom (paññā). Examining the way in which such qualities are described and classified in early Buddhism-with special reference to their treatment in the Visuddhimagga (Path of Purification) by the fifth-century Buddhist thinker Buddhaghosa-the present article employs a comparative method in order to identify the Buddhist catalog of virtues. The first part sketches the characteristics of virtue as analyzed by neo-Aristotelian theories. Relying on these accounts, the second part considers three lists from early Buddhism as possible catalogs of virtue: (1) the components of ethical conduct (sila), (2) the 37 factors that contribute to awakening (bodhipakkhiyā dhammā), and (3) the wholesome (kusala) or beautiful (sobhana) mental factors (cetasika). I then raise the question of why the Buddhist tradition developed several classifications of virtue, whereas the Western tradition of virtue ethics used a single category. Appealing to the connection between the virtues and living well (eudaimonia) in the eudaimonistic version of virtue ethics, I propose that one of the reasons why Buddhism developed multiple lists of virtues is its pluralistic acceptance of different modalities of living well and associated practices, in MacIntyre's sense of the term. These modalities and practices are not equal, but are ordered hierarchically. Accordingly, I conclude that Buddhist ethics ought to be seen as a pluralist-gradualist system rather than a universalist theory.
\end{abstract}

Keywords: Aristotle, Buddhaghosa, Buddhist ethics, Eudaimonia, Virtue ethics, Visuddhimagga

If Buddhist ethics is virtue ethics, then what are its virtues? Although the answer to this question seems all too obvious - qualities such as compassion, generosity, and patience immediately spring to mind - treatments of this problem in Buddhist philosophy are not as systematic as one might hope and therefore require further clarification (Tachibana 1926; reprint 1987, 57; Cooper and James 2005, 90-1). The present article will offer one such analysis by pursuing a comparative investigation that will rely on

HANNER, OREN: Postdoctoral Fellow, Department of Comparative Religion, The Hebrew University of Jerusalem, Israel, and Research Fellow, Numata Center for Buddhist Studies, Hamburg University, Germany. Email: oren.hanner@mail.huji.ac.il 
neo-Aristotelian ethical theories in order to identify the closest Buddhist category to virtue. This inquiry will focus on three sets of good qualities that may constitute a Buddhist catalog of virtues, with reference to their treatment in The Path of Purification (Visuddhimagga), a formative text of the Theravāda tradition by the fifth-century CE Buddhist scholar Buddhaghosa. ${ }^{1}$ I will argue that this inquiry's findings carry implications for how Buddhist normative ethics is to be understood more broadly: rather than a universalist system - one which prescribes moral principles that are equally applicable to all moral agents - Buddhist ethics should be seen as a pluralistic and gradualist system. ${ }^{2}$ My reading will emphasize the link between possessing and exercising the virtues on the one hand and living well (eudaimonia) on the other. In the spectrum of virtue theories, then, the inquiry will depart from an understanding of Buddhism as a eudaimonistic theory (van Zyl 2015) as opposed to agent-based, sentimentalist, or care accounts of virtue ethics. ${ }^{3}$ Here, the eudaimonistic interpretation will serve as a hermeneutic model allowing an exploration of Buddhist ethics from a perspective that raises new questions about Buddhist normativity. I will not engage, however, in a defense of the aretaic interpretation of Buddhism. ${ }^{4}$

The first part of the paper will map the contours of virtue as analyzed by neoAristotelian thinkers in the late twentieth century, fleshing out earlier comparative analogies between Buddhist morality and virtue ethics. ${ }^{5}$ Philosophers such as Julia

\footnotetext{
${ }^{1}$ Translations are from Buddhaghosa, Visuddhimagga; trans. Bhikkhu Ñānamamoli (1956; $4^{\text {th }}$ edition 2010), with occasional modifications.

${ }^{2}$ As will become clear, the version of virtue ethics that I will attribute to Buddhism is pluralistic in the sense that it acknowledges multiple legitimate conceptions of living well (eudaimonia) and virtuous moral character rather than in Christine Swanton's (2003 and 2015) sense of admitting more than one foundation of virtue; in Swanton's taxonomy, my reading of Buddhist ethics is in fact monist in that it adheres to one ground of virtue only: the good for an individual (Swanton 2015, 213). Nor, in this case, is it pluralistic in Edelglass's (2006) sense of the term - that is, in giving equal weight to elements from different moral theories, Aristotelian, Kantian, and utilitarian - as the reading that I will present focuses on virtue ethics alone. Similarly, this version is gradualist in its prescription of different, progressively evaluated modalities of its virtue theory which take into consideration the agent's moral development (as noted by MacKenzie 2018a, 165) rather than in the sense of Peter Harvey's suggestion that Buddhism prescribes norms from different moral theories (referring, like Edelglass, to Aristotelian, Kantian, and utilitarian theories) according to the agent's level of maturity (Harvey 2000, 51).

${ }^{3}$ On the agent-based, sentimentalist, and care variations of virtue ethics, see Slote 2001; Frazer and Slote 2015; and Noddings 2015, respectively.

${ }^{4}$ Virtue ethical readings of Buddhism have been advanced by Keown 1992; Cooper and James 2005; Sahni 2007; Fink 2013; and, more recently, MacKenzie 2018a. I am inclined to agree with interpreters like Clayton (2006), who hold that Buddhism (in this case, even within its early strata) embraces ethical ideas that are the hallmarks of more than one Western moral tradition. Consequently, in this paper my approach is closer to Vasen 2014 and Vasen 2018, in which virtue ethics is applied as a hermeneutical framework rather than a definite view of the nature of normative Buddhist ethics.

${ }^{5}$ The two core concepts of Greek and Hellenistic ethics are the ideas of living well and virtue (aretê), yet it is the former that has received the bulk of attention in modern studies of Buddhist ethics (most notably in Keown 1992, 196-203, and Cooper and James 2005, 68-73; cf. Collins 1998, who refers to the possible analogy between eudaimonia and the Buddhist states of Nibbāna and Brahmā world, though he largely rejects it). Studies that embarked upon an effort to locate the Buddhist catalog of virtues can be seen to employ three main methods of inquiry. The constructive approach, taken by scholars like Tachibana 1922; reprint 1987, and Cooper and James 2005, suggests that through surveying key
} 
Annas and Philippa Foot offer a historical account of virtue derived from Greek and Hellenistic philosophy, whereas Alasdair MacIntyre, in his influential study After Virtue, distills a theory of virtue that aims to be applicable to any aretaic system, in any tradition or historical period. Both descriptions are illuminating when used as a lens for analyzing Buddhist virtues. Building on these foundations, the paper will examine three key, ethically relevant lists which are treated in the Visuddhimagga and whose items display, to a greater or lesser degree, the philosophical characteristics of virtue. In the final part, I will suggest that early Buddhism propounds multiple sets of virtues because it also recognizes different conceptions of living well and practices, indicating that the nature of this virtue theory is pluralist and gradualist.

\section{NEO-ARISTOTELIAN ANATOMIES OF VIRTUE}

There are two currents that are particularly notable in the wake of renewed twentiethcentury interest in virtue ethics. One sketches a historical notion of virtue drawing on Greek and Hellenistic philosophy, while the other devises a modern theory of virtue that sets out to offer an alternative to the hegemonic utilitarian and deontological systems. For both accounts, the diverse nature of this notion presents a significant complexity. Ancient thinkers defined virtue in different, sometimes contradictory ways and were divided on which qualities were to be included in the catalog of virtues. Although the majority of them agreed on the inclusion of the four cardinal virtuescourage, temperance, practical wisdom, and justice - differences arose regarding their relative importance, how they should be interpreted, and the manner in which they are acquired. This challenge is more insistently faced by modern accounts, as they consider an even wider range of historical concepts - stretching into modernity - in their attempt to reveal the ethical relevance of these concepts to contemporary times.

The question then arises as to whether the difficulties that ensue from the variety of views can be overcome. Responding to this question, thinkers like Julia Annas (1993) and Philippa Foot (1978) draw an outline of virtue that is common to many of the classical theories which specifically relies on Aristotle's analysis of this concept. According to Annas, the classical version of virtue underscores three main aspects of this idea: (1) virtue is a stable disposition to act, which exists in the soul and involves choices; (2) it has an affective aspect, measured according to the virtuous agent's ability to do the right thing with little or no internal opposition; and (3) it has an intellectual

Buddhist moral teachings, alongside relevant idioms, notes, and doctrines from various scriptures, we can distill a set of good qualities that represent Buddhism's set of virtues. The single list method, followed by Keown 1992 and Sahni 2007, calls upon the intuition that if Buddhism provides a repository of qualities to be developed by a virtuous practitioner, then these qualities must be classified under a clearly defined category, one that is produced by the tradition itself, but which also shares certain features with other philosophical and religious concepts of virtue. Finally, the moral ideal method, adopted by MacKenzie 2018a, proposes that a useful way to arrive at a list of Buddhist virtues is to concentrate on those qualities which partly constitute the awakened state of a Buddha, or, in other words, to take the moral ideal of Buddhism as the source from which its virtues can be derived. Here, I will seek to preserve the basic intuition of the single list approach: that the Buddhist catalog of virtues is to be found in a single category provided by the tradition itself. 
aspect, consisting in the agent's coherent understanding of the reasons for acting virtuously based on reflection and self-examination.

According to Annas, Aristotle offers the most elaborate clarification of the first aspect. In the Nicomachean Ethics, he carries out an examination which is intended to reveal the nature of virtues. Taking it as a given that virtue is a thing that is "found in the soul", he claims that there are three things that can be described in this way: feelings, such as appetite, anger, fear, confidence, and the like- "in general things accompanied by pleasure or pain" (Aristotle, Nicomachean Ethics, 1105b; trans. and ed. Crisp 2000); capacities, "the things on the basis of which we are described as being capable of experiencing these feelings - on the basis of which, for example, we are described as capable of feeling anger, fear or pity" (ibid.); and states,

those things in respect of which we are well or badly disposed in relation to feelings. If, for example, in relation to anger, we feel it too much or too little, we are badly disposed; but if we are between the two, then well disposed. (ibid.)

Virtue, then, belongs to one of these three categories.

Aristotle rules out the possibility that virtue is a feeling for two reasons: first, we are morally evaluated for having or lacking virtues, but never for having feelings; second (clarifying the first reason), feelings are not a matter of deliberate, rational choice. In his typical way of approaching philosophical issues by appealing to common beliefs, Aristotle notes that when we have feelings, we are said to be moved by them, whereas the moral virtues do not move us, but are rather our states. In modern terms, Annas writes, "we are not responsible for the way we feel, since it is not entirely under our control; but we are responsible for being virtuous or depraved, and praised or blamed accordingly" (Annas 1993, 49). Thus, virtue must have an affinity not only to our feelings, but also to the way in which we manage them. In other words, virtues and vices are the manner in which a person makes himself and how he chooses to be.

Next, Aristotle examines the capacities and arrives at a similar conclusion. The virtues cannot be capacities for a similar reason: we are not morally evaluated on the basis of our capacities, Aristotle argues, since we possess them by nature, but "we do not become good or bad by nature" (Aristotle, Nicomachean Ethics, 1106a). In other words, the virtues are not part of the fundamental constitution with which we are born. What makes us good or bad, and accordingly, what we may be praised or blamed for, is the way in which we handle the given facts of our life out of deliberate choice. Since we are not sufficiently responsible for our feelings or capacities, they cannot constitute virtues. Aristotle concludes, by a process of elimination, that virtue is a state (hexis). However, Annas comments,

in some ways Aristotle's word hexis answers better to our word "disposition" than to "state": a virtue like courage is a disposition because it is a condition because of which I am so disposed as to act in brave ways; and this is what hexis is. (Annas 1993, 50) 
Importantly, moral virtue as a disposition is characterized by being intentional. Aristotle defines virtue as a state that involves choice, and this is true in two senses: first, it is built up from repeated choices, and second, it is exercised in making a choice. In this, Annas argues, virtue is different from habit, which is built up mindlessly, without deliberation or decision (51).

Virtue is not only a disposition to act in certain ways, but also a state that concerns the agent's character, feelings, and emotions. This is its affective aspect. A virtuous person's character is considered to be developed to the extent that he knows the right thing to do in each moment and takes pleasure in doing it. Committing a wrong-doing, at the same time, repels those who possess a developed character, and they are not tempted to pursue such courses of action (55). Greek and Hellenistic philosophers distinguish between those who do the right thing but need to struggle with their feelings and those who do the right thing without experiencing any conflict; that is, they act wholeheartedly and take pleasure in the action. This distinction between the two types of moral agents is considered to reflect different levels of ethical maturity. The latter type is deemed more advanced from an ethical point of view. In addition, the affective aspect of virtue refers to the view that an agent's capacity to regulate his feelings and emotions through the cultivation of virtue correlates with his ability to perceive the right thing to do. The intellectual knowledge that a certain action is virtuous is not sufficient, according to Annas's analysis. Changes in ethical belief have to take root in the agent's emotional life in order for them to manifest in his behavior. The virtuous person, then, not only does the right thing, but also has the right kind of emotion with respect to what he does $(54)$.

In this regard, Philippa Foot (1978) adds that virtues have a corrective role, being responsible for the proper regulation of our emotions. Each virtue stands at a point where there is a temptation to be resisted or a deficiency of motivation to be rectified. Courage stands at the point at which fear operates as a temptation; temperance stands at the point at which the desire for pleasure constitutes a temptation. In fact, Foot's claim is that virtues only exist because vices - for instance, fear or the desire for pleasure-operate as temptations. Often, we want to run away not only when this is the right thing to do, but also when we should combat a threat; we wish to enjoy pleasures not only when it is appropriate to do so, but also when it is not. If human nature had been different, Foot observes, there would have been no need for these corrective dispositions, since fear and pleasure would have served as excellent guides to behavior (9). Other virtues, such as justice, are there to correct deficiencies of motivation. Justice, according to Foot, does not correlate with any particular disposition or desire to be restrained, since many different desires and dispositions may lead to injustice. Instead, justice corresponds to a deficiency in motivation that is in need of rectification. This, then, is the affective aspect, according to Foot: virtue is necessary in the light of emotional temptations and deficiencies of motivation that affect human beings, and its role is to correct them.

Finally, virtue has an intellectual aspect. Annas explains that alongside its affinity to our feelings and emotions, virtue requires an intellectual understanding and a capacity for reflection. "The virtuous person is not just the person who does in fact do 
the morally right thing, or even does it stably and reliably", she writes. "She is the person who understands the principles on which she acts, and thus can explain and defend her actions" (Annas 1993, 67, emphasis in original). In other words, virtue rests on an understanding or knowledge of those principles that underlie moral action. In order to be virtuous, the moral agent needs to engage in a process of reflection and thereby achieve a unified grasp of the general principles that form the basis of his patterns of action and decision-making. In Greek philosophy, this intellectual element is frequently illustrated by an analogy to expertise or skill (technê). Virtue, like the expert's mastery of sculpture or carpentry, is the point at which the agent reaches an intellectual grasp of the universal, of that which is common to particular cases. The expert is capable of forming a reliable judgment with regard to what he does; or, in other words, he is capable of providing reasons for doing things this way rather than another or why a certain craft is better than another. Similarly, the virtuous agent has a unified or coherent understanding of his expertise; i.e., the domain of each of the virtues.

In addition to these three aspects, it is important to underline that in eudaimonistic virtue theories, the value of virtues lies in their close connection to living well, which is their final end. "Cultivating the virtues is worthwhile", writes Annas, "because living virtuously will constitute my living my life as a whole in a way that lives it well, in a way which it is valuable to live" (2006, 520, emphasis in original). It is virtues, then, that enable the attainment of a well-lived life.

While Annas's and Foot's descriptions of virtue stem from ancient philosophy, Alasdair MacIntyre sets out a modern virtue theory that engages in ethical problems emerging from modern and post-modern thought. In his book After Virtue $\left(1981 ; 3^{\text {rd }}\right.$ edition 2007), he paints a gloomy picture of the state of modern moral discourse, which fails to measure up to rational lines. Virtue theory, MacIntyre believes, may remedy the shortcomings of this discourse. His theory is intended to be applicable to conceptions of virtue from different places and times: those of Homer, Aristotle, the Stoics, and Epicurus; Christian and medieval views; and virtue as theorized by early modern thinkers such as David Hume and Baruch Spinoza. According to MacIntyre, the variety of conceptions does not impede the identification of common essential features. Starting from this assertion, he advances a thesis that relies partly on a philosophical inquiry and partly on insights from sociology and also offers a template designed to fit different understandings of virtue.

One of the characteristics of virtue, according to MacIntyre, is that its realization requires a prior understanding of certain features of social and moral life - an understanding in terms of which the concept of virtue is defined and explained. In Aristotle's thought, for example, the concept of virtue is subordinate to the concept of living well, which is identified as the telos of human activity, while in Homer's works, virtue is subordinate to the concept of social role. MacIntyre seeks to develop this insight into an understanding of the general foundation that is required for an understanding of virtue. To do so, he relies on two background notions - "practice", as the framework in which virtue manifests, and "the narrative unity of human life", which defines the human good. 
MacIntyre describes the social and moral backdrop of the virtues using the notion of practice. His main claim is that a particular type of practice provides the arena in which the virtues are exhibited and in terms of which they are defined. MacIntyre's definition of this idea comprises several elements:

By a "practice" I am going to mean any coherent and complex form of socially established cooperative human activity through which goods internal to that form of activity are realized in the course of trying to achieve those standards of excellence which are appropriate to, and partially definitive of, that form of activity, with the result that human powers to achieve excellence, and human conceptions of the ends and goods involved, are systematically extended. (187)

This passage needs to be unpacked. First, what is meant by a "coherent and complex form of socially established cooperative human activity"? MacIntyre does not elaborate on this, but he does mention several examples: the games of football and chess; the inquiries of physics, chemistry, and biology; and the work of the historian, the painter, and the musician. These examples show that a practice is not only a framework of moral activity. Rather, any socially established cooperative human activity, such as research or multiplayer games - and for our purposes, a spiritual or religious path — is a practice, and the conceptual framework of virtues (in the ethical sense of the word, as opposed to the virtues of the athlete or artist) is but one of them.

Through participation in a practice, the goods internal to it are achieved. MacIntyre distinguishes between external and internal goods. External goods are those which are contingently attached to the practice according to social circumstances, as in MacIntyre's example of a child who learns to play chess despite having no particular desire to play the game and who is offered sweets in order to encourage him to play and win. Motivated in this way, the child plays and does so in order to win, but as long as it is only the sweets that give him a reason to play, he does not have any reason not to cheat. The sweets are external goods. By contrast, internal goods cannot be achieved in any other way than through the practice itself. They are internal in two senses: they can only be described using terms afforded by the practice and they can be recognized and known only on the basis of the experience gained through participating in that practice. Those who lack experience in the relevant practice are incapable of evaluating its internal goods. An important difference between the two types of goods is that external goods are such that when they are achieved, they become the property of a particular individual, whereas internal goods are such that achieving them benefits the entire practice community.

The distinction between external and internal goods allows for an initial definition of virtues: "A virtue is an acquired human quality the possession and exercise of which tends to enable us to achieve those goods which are internal to practices and the lack of which effectively prevents us from achieving any such goods" (191). According to MacIntyre, three virtues are essential for the achievement of internal goods in any practice. These are justice, courage, and honesty, which are necessary because a person who does not exercise them bars himself from achieving the standards of excellence or 
the goods that are internal to the practice. Each practice requires a particular kind of relationship to exist between its participants. Anyone who participates in the practice needs to learn to recognize who deserves what (justice), to take upon himself the risks he may face along the path (courage), and to be attentive to what others say about his inadequacies and to reply with attention to the facts (honesty). These virtues are necessary for the maintenance of those types of relationships that enable the practice.

At this point, MacIntyre introduces the second background idea: the narrative unity of human life. A central role of the virtues in pre-modern ethical systems was to make the individual's life a unified one. Thus, MacIntyre claims, we ought to ask whether it is

rationally justifiable to conceive of each human life as a unity, so that we may try to specify each such life as having its good and so that we may understand the virtues as having their function in enabling an individual to make of his or her life one kind of unity rather than another. (203)

While the answer to this question was self-evident to thinkers of the pre-modern eudaimonistic tradition, MacIntyre observes that in contemporary times, any attempt to imagine human life as a whole, which would give the virtues an adequate telos, encounters philosophical and social obstacles (204). The social obstacles emerge from the way in which modernity split human life into fragments - work and leisure, private and public life, childhood, middle age, and old age-with each fragment having its norms and expected set of behaviors. The philosophical obstacles originate in analytical philosophy, which has adopted the tendencies to think about human action in atomistic terms and to analyze complex actions and transactions in terms of simple components, as well as in existentialism, which divorces the individual from the roles he fulfills, to the point that life resembles a series of unconnected episodes.

This fragmentation of the self renders the virtues meaningless, as a self that is separated from its roles is stripped of the foundation of social human relationships in which the virtues operate. Similarly, MacIntyre claims, it is not possible to isolate human action and understand it outside of its context. A single segment of a given human behavior can be characterized in various different ways depending on the intention underlying it, which in turn cannot be understood independently of the sequence of actions in which it is embedded or its cultural, social, and historical background. Without getting into the minute details of MacIntyre's philosophical move, his conclusion is that "narrative history of a certain kind turns out to be the basic and essential genre for the characterization of human actions" (208) and that "man is in his actions and practice, as well as in his fictions, essentially a story-telling animal" (216). The narrative to which MacIntyre refers is our life story, the connection that we make between our actions over time, from birth to life to death. Only in this way, on the basis of our and others' narratives and the relationships between them, do our actions take on their meaning. Furthermore, the narrative is the thread running through an individual's life, creating its unity. Above all, this narrative enables us to determine the human telos and, on this basis, to identify the virtues (218-9). In other words, the unity 
that is created by the narrative gives human life its meaning, and from this meaning, the virtues are derived.

It is in this way that MacIntyre departs from the broad concept of a practice, which includes the game of football, the inquiry of physics, and so on, and centers the discussion on ethical practice, for the virtues which make it possible to acquire the goods that are internal to the practice are the same dispositions that will sustain us in our quest for our personal and human good, as expressed in our narrative. Their role is to enable us to overcome the misfortunes, dangers, temptations, and distractions that we will encounter along the path.

\section{BUDDHIST CATALOGS OF VIRTUES}

The principle that will guide my next inquiry is that Buddhist virtue, if it is to be recognized as such, has to meet one or more of the two descriptions given in the previous section; that is, it is either (1) a good mental disposition, which has an affective dimension (a corrective function with respect to our emotions, etc.) and an intellectual dimension (an encapsulation of a rational justification for its being virtuous that rests on a coherent understanding of the ground for moral judgment), or, following MacIntyre, (2) an acquired human trait whose possession and exercise enable the agent to acquire the goods that are internal to Buddhist practice, according to the Buddhist definition of human good. ${ }^{6}$ To this, I would like to add a second condition: the list of Buddhist virtues should be exhaustive and mutually exclusive; that is, it will not omit any virtue endorsed by Buddhist thought, and, of course, will not include any item which is not a virtue. Buddhist literature formulates its teachings, including its ethical teachings, using a multitude of lists, whose number reaches several hundred (Gethin 1992; reprint 2001, 20). Here, I have chosen to examine, in broad strokes, only three canonical lists from the early strata of Buddhism: (1) the components of ethical conduct (sīla), (2) the 37 factors that contribute to awakening (bodhipakkhiyā dhammā), and (3) the wholesome (kusala) or beautiful (sobhana) mental factors (cetasika). I will center on these lists because they are both interesting from an ethical point of view and aim to present a comprehensive analysis of what can be seen as the moral virtues of early Buddhism.

The Buddhist practice which is probably most identified with an ethical system is the practice of silla. Sìla is rendered in English in various ways, including "virtue" (Harvey 2000), "morality" or "moral conduct" (Keown 1992; Heim 2020), and "moral discipline" (Bodhi 2005; Śantideva 2016). It is considered to be the moral aspect of both the Noble Eightfold Path — subsuming Right Speech, Right Action, and Right Livelihood-and the six perfections of the Bodhisattva. Its portrayal in the Visuddhimagga is one of several different expositions in the Buddhist corpus. ${ }^{7}$

\footnotetext{
${ }^{6}$ For further comparison between Buddhist ethics and MacIntyre's thought in After Virtue, see Vasen 2014 and Vasen 2018.

${ }^{7}$ On the understanding of sìla in the Pāli canon, see Keown 1992, 25-56; on the notion of síla in Śāntideva's thought, see Clayton 2006, 72-6; on śíla in Asañga's work, see Asaniga and Tsong-kha-pa
} 
Buddhaghosa opens his discussion of silla with a number of questions that are relevant to the present inquiry: What is sīla? In what sense is it sīla? What are its characteristic, function, manifestation, and proximate cause? How many kinds of sīla are there (I.16)? In reply to the question of what sila is, he gives the following definition:

It is the states beginning with volition (cetana $)$ present in one who abstains from killing living things, etc., or in one who fulfils the practice of the duties. For this is said in the Pațisambhidā: "What is sīla? There is sīla as volition (cetanā), sīla as consciousnessconcomitant (cetasika), sìla as restraint (samvvara), sīla as non-transgression (avītikkama)." (I.17)

We may note that Buddhaghosa weaves together various motifs from the domain of moral theory, and the mention of action as a defining feature of silla particularly stands out. Actions such as abstaining from killing-and by this, Buddhaghosa means abstention from the 10 unwholesome actions (dasa-akusala-kammapatha $)$, as we will see later on-define those states which are silla. Similarly, the passage mentions the set of duties to be fulfilled-here, Buddhaghosa alludes to moral precepts such as the vinaya - and it, too, is used to describe the states in question. However, at the beginning of the definition stand volition or intending (cetanā) and mental factors (cetasika). Sìla, then, is defined as the cetana or cetasikas of those who abstain from negative actions and fulfill their duties; the root of morality is mental intentionality.

Consequently, it seems that sila is characterized by at least one element in the definitions of virtue: it denotes a group of states or dispositions. These are the intentions of a person who guards the 10 wholesome actions - the counterparts of the unwholesome actions - and fulfills his duties. Indeed, later in the chapter, Buddhaghosa indicates that he sees silla as a disposition, when he writes:

But in the world the nature of such and such beings is called their disposition (silla) of which they say: "This one is of happy silla, this one is of unhappy silla, this one is of quarrelsome sìla, this one is of dandified sīla." (I.38)

After he defines sīla, Buddhaghosa turns to describing its characteristics and nature, where we find another parallel with the Western notion of virtue:

Just as visibleness is the characteristic of the visible-data base ... so also this same composing, described above as the coordinating of bodily action, etc., and as the foundation of wholesome factors (kusala dhammā), is the characteristic of sīla .... While such is its characteristic:

Its function has a double sense:

Action to stop misconduct, then

Achievement as the quality

Of blamelessness in virtuous men.

Blo-bzan-grags-pa 1986, 1-46; for further analysis of sīla in Buddhaghosa, see Heim 2013, 113-6, and Heim 2020, 18-23. 
So what is called silla should be understood to have the function (nature) of stopping misconduct. (I.20-1, emphasis in original)

That is, sìla is described as a habit that participates in behavioral, and consequently emotional, correction. Its essential function is opposing misconduct and it establishes the purity of the virtuous person. Of the three aspects mentioned by Annasdispositional, emotional, and intellectual-it appears that sīla meets the first two. However, if we pay attention to the first part of the paragraph, we will notice that it contains another, somewhat different description of sīla, which may cast doubt on our initial conclusion: sĭla, Buddhaghosa tells us, is the foundation of wholesome factors. If so, is sìla the moral disposition itself, or rather merely a means of forming a moral disposition? Should we regard the varieties of silla as virtues, or is their function nothing more than to assist in the cultivation of virtues?

One possible answer is that sīla has both functions. It may be argued that sìla has a double meaning: on the one hand, it is the wholesome disposition itself; on the other, it produces the disposition. This makes sense if we assume that every human action contributes to the development of an equivalent habit (as Aristotle and Annas hold) and this, of course, is a premise of Buddhist karman theory. A violent deed, for instance, results from a violent intention and at the same time leads to the habit of acting violently in the future. Indeed, this can be understood from the way Buddhaghosa points to silla's double meaning in the following etymological analysis:

In what sense is it sìla? It is sìla in the sense of composing (sìlana). What is this composing? It is either a coordinating (samādhāna), meaning non-inconsistency of bodily action, etc., due to virtuousness; or it is an upholding (upadhāraṇa), meaning a state of basis ( $\bar{a} d h \bar{a} r a)$ owing to its serving as foundation for wholesome factors. For those who understand etymology admit only those two meanings. (I.141)

The first meaning of silla is the "composing" or "coordinating" of bodily and vocal actions - that is, moral behavior-while in its second sense, it is the support of wholesome mental states, or, in other words, that which establishes them.

The next question that Buddhaghosa raises, which he answers at great length, is how many kinds of sìla there are. He proposes to classify the kinds of sìla in several ways, and in the course of his classification, he clarifies the meaning of silla in practice; that is, what it means to live in accordance with sîla (I.25-141). As the text advances, sìla reveals its deontological dimension and Buddhaghosa stresses the observance of precepts or moral duties. This latter sense overshadows the initial sense that sila receives in the definition; namely, the intending underlying the action. In a twofold division, Buddhaghosa distinguishes between sìla as a manner of keeping and avoiding (cāritta-vāritta). "This should be done' is keeping; not doing what is prohibited ... 'This should not be done' is avoiding", he writes (I.26, emphasis in original). The next twofold division relates to minimal rules of conduct (abhisamācārika) and fundamental rules of conduct (ädibrahmacariyaka), which include the self-liberation (pätimokkha) vows of the vinaya (I.27). Later on, the Visuddhimagga enumerates normative rules of 
conduct that originate from family or local customs, and so on (I.41). Although all of this appears to imply that silla is a deontological principle, if we take Buddhaghosa's early comments into account I would claim that in its essence sìla is an internal state that manifests and is cultivated through action. This reading presupposes a close proximity between the language of virtues and the language of human behavior (Fink 2013, 670) and suggests that virtue can be defined, as well as exemplified, by recourse to the types of action it motivates.

The second candidate for a Buddhist catalog of virtues to be examined is the list of 37 factors that contribute to awakening (bodhipakkhiya dhammā). At first glance, this collection of states seems to constitute an exhaustive list of Buddhist virtues, for two main reasons: first, in the post-canonical literature, the factors that contribute to awakening are equated with the entire spiritual path (magga; Gethin 1992; reprint 2001, 23), and as such, this scheme is by definition the most comprehensive list of factors; second, the reason why the items are included in the list is that cultivating them assists one in acquiring important goods that are internal to Buddhist practice-above all, wisdom and awakening. According to Buddhaghosa, all 37 factors are present in a single mind moment at the time in which the four knowledges of the stream-enterer, the once-returner, the non-returner, and the arahant arise (Buddhaghosa, Visuddhimagga, XXII.39). Although the expression "factors that contribute to awakening" only rarely appears in the Pāli Nikāyas, in later commentarial literature it is employed as a general concept that signifies the essence of the practice of the Buddha's teachings. The list is a combination of seven different groups of factors, which are scattered throughout the three baskets of the Pāli canon and which were consolidated into the broader scheme only in later commentarial works.

These are the seven groups: ${ }^{8}$ (1) The four foundations of mindfulness (satipatthāna), which comprise awareness of the body (rūpa), feelings (vedanā), the mind (citta), and mental objects (dhammā). This prevalent scheme is a complete array of meditative practices that are intended for the development of mindfulness and have the essence of mindful contemplation of phenomena. (2) The four right efforts (sammappadhāna)-likewise familiar from numerous early sources-include the effort to eradicate unwholesome states of mind which have arisen, the effort to prevent the arising of unwholesome states which have not yet arisen, the effort to develop wholesome states which have not yet arisen, and the effort to preserve existing wholesome states. This fourfold division is comparable to Right Effort (sammāvāyāma), the sixth component of the Noble Eightfold Path. (3) The four bases of success (iddhi-pāda) are the desire to act (chanda), strength (viriya), the mind (citta), and investigation (vimamsā). The application of these four elements leads to success in meditative practices and also to supernormal powers (Buddhaghosa, Visuddhimagga, XII.50-3).

The following two groups are (4) the five spiritual faculties (indriya) and (5) the five spiritual powers (bala), which call for special care in the present context. The two

\footnotetext{
${ }^{8}$ Gethin 1992; reprint 2001 offers a thorough study of these factors and their formulations in the Pāli canon and commentary literature. The following survey is based on his work.
} 
are identical in terms of their five constituents - confidence (saddhā), strength (viriya), mindfulness (sati), concentration (samādhi), and wisdom (pañ $\tilde{a} \vec{a}$ - but they do not have the same status. The faculties are seen as items which exercise control in their own domains: confidence governs the sphere of commitment (adhimokkha), strength the sphere of "taking on" (paggaha), mindfulness the sphere of "standing near" (upatthāna), concentration the sphere of non-distraction (avikkhepa), and wisdom the sphere of seeing (dassana), while the powers are the very same items being stable and deemed undefeatable by their opponents, which are distrust (assaddhiye akampiyam), laziness (kosajja), heedlessness (pamāda), agitation (uddhacca), and ignorance (avijjā) respectively.

In the context of classical Indian thought, the concept of indriya should be understood as an entity or capacity which exerts a certain kind of power, strength, influence, or control over its domain. In classical Indian philosophical literature, it usually denotes the five sense organs - the eye, ear, nose, tongue, and body - and oftentimes, albeit not always, the mind is added as the sixth sense organ. In Buddhist thought, the full classical list of faculties includes 22 entries. These are subsumed under five groups, the first of which is the aforementioned list of sense faculties. Another group is the set of spiritual faculties, which appears in the list of 37 factors that contribute to awakening. Another central group of items characterized as indriyas is the set of feeling faculties, with five items: the pleasure faculty, the pain faculty, the joy faculty, the grief faculty, and the equanimity faculty (XVI.1). What all these indriyas have in common, according to the Pāli Nikāyas, as well as the commentarial tradition, is that each of the faculties functions as a ruler (XVI.4-5).

At this point, we can return to the main question of whether the list of 37 factors can serve as a Buddhist category of virtues. In my opinion, the last analysis shows that the indriyas do not meet the definition of virtue, and for this reason, neither does the list of 37 factors as a whole. Why are the indriyas not virtues? First, the semantic field to which the term belongs - that of "capacity", "strength", and "power"- distinguishes them from virtues. Virtue is a habit or disposition to think or act in a certain way rather than an ever-present faculty. Additionally, the philosophical characterization in early and commentarial texts implies that an indriya is not a disposition or state characterizing a particular individual; rather, it is common to all beings (unless they are impaired, of course) whether they choose to have these faculties or not and whether they cultivate them or not. The list includes capacities that we possess from birth. Above all, it seems that a more appropriate analogy would be between the categories of indriya and bala and the Aristotelian category of capacities. Recall that Aristotle does not accept any mental element over which we do not exercise choice as a virtue. He justifies this claim by noting that we are not morally praised or blamed for what we cannot choose (that is, our capacities and feelings). Indeed, the sense organs with which we are born, just like the capacity to feel pleasure or pain, are things over which we do not exercise choice and, accordingly, for which we are not subject to moral judgment. Indriyas are better described as "things in virtue of which we are said to be capable of feeling", to follow Aristotle's wording. 
The list of 37 factors, although not a pure catalog of virtues, is interesting as it reveals a complexity with regard to recognizing such a Buddhist classification - a complexity that results from the frequent reoccurrence of good qualities in different categories. This problematic is distinctly exhibited by the final two groups: (6) the seven members of awakening (bojjhanga) and (7) the Noble Eightfold Path. The members of awakening are a set of qualities that lead to spiritual liberation, and they include mindfulness (sati), discrimination of dhamma (dhamma-vicaya), strength (viriya), joy (pīti), tranquility (passaddhi), concentration (samādhi), and equanimity (upekkhā). Three of the seven members have already been observed in the previous groups and carry similar meanings: the mindfulness member of awakening is equivalent to the mindfulness indriya, the mindfulness bala, and the four foundations of mindfulness; the strength member of awakening is equivalent to the strength indriya and the strength bala, Right Effort, and the four right efforts; and the concentration member of awakening is equivalent to the concentration indriya, the concentration bala, and Right Concentration (samm $\bar{a}-$ sama $\bar{a} h \mathrm{~d} i$ ) of the Eightfold Path.

Two of the members partly overlap items in other groups covered above. Discrimination of dhamma is an alternative formulation of the wisdom indriya and the wisdom bala, whose particular meaning is derived from the conceptual world of Abhidhamma literature. As an indriya, wisdom concerns the realization of the four noble truths, but the term "discrimination of dhamma" points to the connection between Dharma as the corpus of Buddhist teachings and dhammas, the components of the teachings, as Rupert Gethin has established on several occasions (1992, 147-54; 2004). Similarly, equanimity is a term that is pregnant with meaning in early Buddhist thought. Apart from being one of the seven members of awakening, upekkhā can frequently be found in the Pāli canon in the context of the aggregate of feelings (vedana $)$, meditative absorptions (jhāna), and the four divine abidings (brahma-vihāra), which will also be mentioned below. Used in the present context, equanimity represents a balance with respect to phenomena (dhammas) that arise simultaneously. Finally, two other members are entirely distinct: joy, as a member of awakening, denotes an emotional satisfaction that is intrinsic to the spiritual life and is specifically associated with the process in which the mind becomes satisfied and tranquil, while tranquility is closely linked to joy, but is described as a bodily experience.

The Noble Eightfold Path, being a fundamental teaching of early Buddhism, does not require further elaboration here, but one point to note, once again, is the reoccurrence in this context of moral elements that appear elsewhere in the list of 37 factors or in other places, such as in the category of silla. As mentioned, Right Effort has the same function as the four right efforts and the strength member of awakening, Right Concentration has a similar role to that of the concentration member of awakening, and the three trainings of Right Speech, Right Action, and Right Livelihood encompass, according to Buddhaghosa, the purview of silla.

With this in mind, can the list of 37 factors be seen as a Buddhist catalog of virtues? At first glance, the answer must be negative. The list contains entries with the functions and features of innate capacities rather than virtue. However, this verdict ought to be qualified. The 37 factors themselves are a compilation of seven separate lists, and when 
they are seen in this way, some of the sub-lists may nevertheless serve as virtues. For example, the four foundations of mindfulness are a detailed description of mindfulness, and the four strengths are an elaboration of the idea of strength (viriya). Both mindfulness and strength are wholesome mental factors, which may be acknowledged as Buddhist virtues (Keown 1992, 63; Sahni 2007, 109-13). Examined in this light, the list of 37 factors constitutes a partial catalog - a scheme that provides us with some of the virtues of early Buddhism, while including other factors that are not virtues.

The third and final category that I will examine comes from Abhidhamma literature, whose categories, according to Damien Keown, shed light on the nature of Buddhist ethics (1992, 58). More specifically, within the conceptual framework of the Abhidhamma, Keown maintains that the classification of wholesome factors (kusala dhamma) and unwholesome factors (akusala dhamma) are the closest to the Western concepts of virtues and vices respectively (63). ${ }^{9}$ This view is supported by Pragati Sahni $(2007,109-13)$. Of the many kinds of factors that make up the person in the Abhidhamma analysis, those belonging to the groups of minds (citta) and mental factors (cetasika) are particularly pertinent, as they may be evaluated as morally wholesome or unwholesome. The Theravāda Abhidhamma system recognizes 89 classes of mind, of which 21 are wholesome. The causal roots of the wholesome factors are non-desire (alobha), non-hatred (adosa), and non-delusion (amoha), whereas the unwholesome factors are rooted in desire (lobha), hatred (dosa), and delusion (moha). Mental factors are basic mental entities that accompany the main mind. According to the Theravāda Abhidhamma, they consist of 52 kinds and are either wholesome, unwholesome, or morally neutral.

Sahni enumerates 14 unwholesome mental factors which she recognizes as the Buddhist vices (111) -including confusion (moha), immodesty (ahirika), unscrupulousness (anottappa), and restlessness (uddhacca) - and 12 wholesome cetasikas (out of the 25 mentioned in Theravāda sources) - including faith (saddhā), mindfulness (sati), modesty (hiri), scrupulousness (ottappa), Right Speech (sammā$v \bar{a} c \bar{a}$ ), Right Action (sammā-kammanta), Right Livelihood (sammāa-àjīva), compassion (karuña), and sympathetic joy (muditā). The list of wholesome mental factors has many of the characteristics expected from a catalog of virtues: the factors are good mental states; they are important qualities that assist a person in obtaining the goods internal to the spiritual path; some of them are opposites of unwholesome mental factors and, as such, oppose and correct the latter; and we are subject to moral evaluation on their basis. It is interesting to note that much like the 37 factors, the list of wholesome mental factors includes elements listed in other moral schemes, such as the four divine abidings (compassion and sympathetic joy) and the seven members of awakening (tranquility and equanimity). In other words, the list of mental factors, while mutually exclusive, partly overlaps other sets of virtues.

\footnotetext{
${ }^{9}$ Of particular relevance and interest is the fact that Keown bases his claim on Foot's and MacIntyre's accounts of virtue. This pertinent analysis, coupled with the observations presented in this article, leads me to call into question Keown's decision to identify the virtues of Buddhism with one category alone, which in my opinion is too narrow an application.
} 
The initial problem with which I opened this paper-namely, "what is the category of moral virtue in Buddhist ethics?"- is now superseded by a different kind of problem: Why do we find so many catalogs of virtues, why do they partially overlap, and why is it that none of them is fully exhaustive of the entire supply of Buddhist good qualities? The comparison explored above indicates that whereas the Western philosophical tradition of virtue ethics, with its many thinkers and scholars, described all virtuous qualities using a single term, aretê, in Buddhism we find numerous categories of virtues. I have mentioned sila, a number of lists from the 37 factors that contribute to awakening, and the wholesome factors, but other categories that are frequently discussed may be added-for instance, the six perfections (pāramitā) of the Bodhisattva or the four divine abidings (brahma-vihära). ${ }^{10}$ It should be noted that none of them is fully exhaustive and that some are not even mutually exclusive, as they overlap other classifications. How is this profusion of lists to be explained? Why did the need arise to put together distinct catalogs of virtues, a tendency that cannot be traced in Western virtue theory? And why do different catalogs contain similar items?

\section{FROM BUDDHIST VIRTUES TO PLURALISM AND GRADUALISM}

The solution that I propose to this issue is based on two considerations. The first takes into account the functional relationship between moral virtues and living well presupposed by classical eudaimonistic virtue theories. The second concerns the place of the virtues and internal goods in MacIntyre's idea of practices. First, recall that eudaimonistic theories see a close connection between the virtues and living well: essentially, the main reason for developing moral virtues is that living virtuously constitutes the state of living well. Given this connection, I would suggest that the linguistic distinction between different categories of virtues indicates a nuanced recognition of different categories of living well. One of the fundamental principles in the philosophy of language, as theorized by Wittgenstein and the Sapir-Whorf hypothesis, is that there is a direct relationship between the categories of our language and the ways in which we understand the world. A plurality of terms for describing a given phenomenon points to our ability to recognize distinct instances of it, uniqueness, and nuances, which requires different linguistic terms. On this interpretation, the multiplicity of terms for moral virtues suggests that the Buddhist tradition also acknowledges various conceptions of living well rather than a single idea. The virtues are classified under several categories because each set of virtues brings about its own

\footnotetext{
${ }^{10}$ It is compelling to view the four divine abidings as a catalog of virtues: Buddhaghosa explains that these mental states balance their "near" and "far" enemies (loving-kindness, for instance, balances greed and ill-will), demonstrating their emotionally corrective role (Buddhaghosa, Visuddhimagga, IX.98101); they are dispositions which, when fully realized, color the moral agent's life as a whole, encompassing dear ones, enemies, strangers, and the agent himself, without any qualifications (IX.812); they are guided by and rooted in an understanding of reality, or wisdom (e.g., IX.38); and even etymologically, both brahma-vihära, as explained by Buddhaghosa, and the Greek term aretê denote "excellence" (IX.106; MacIntyre 1981; $3^{\text {rd }}$ edition 2007, 122-3). For relevant discussions of the four divine abidings, see Heim 2014; Heim 2020, 27-32; MacKenzie 2018a, 158-60; MacKenzie 2018b, 210-2; McRae 2013; McRae 2016; and McRae 2017.
} 
state of living well. The overlap between distinct catalogs that contain similar items is the natural result of different combinations of virtues being conducive to different modalities of living well. ${ }^{11}$

This nuanced classification has a further and deeper ethical significance. The different sets of virtues are associated with different practices, in MacIntyre's sense of the term, and this brings me to my second consideration. As mentioned above, practices are forms of socially established cooperative human activity. These activities prescribe standards of excellence and allow the practitioner to realize the goods internal to them. Additionally, practices involve human conceptions of ends and goods. Within this theoretical framework, virtues take on the meaning of acquired qualities which, through their possession and exercise, tend to enable the practitioner to achieve the goods that are internal to the practice. The frameworks in which the Buddhist sets of virtues are acquired and exercised, I would suggest, meet MacIntyre's definition of a practice. Thus, the refined classification of virtues that is found in Buddhism is also indicative of a plurality of practices, each with their own ends, standards, and internal goods.

To return to some of the categories of virtues mentioned above: each of them, according to Buddhist scriptures, enables the practitioner to realize a well-lived life, as the foremost benefit in an array of goods. Sila creates the conditions for a life of success, which is characterized by a large fortune, a good reputation, freedom from fear in the company of others, an unconfused death, and consequently a happy rebirth in the heavenly realms (Buddhaghosa, Visuddhimagga, I.23). Furthermore, the virtuous person's actions bear much fruit; he is the object of honor and becomes renowned, he is free of mental afflictions, and, by being virtuous, he prevents future suffering (I.159). At the same time, the meditator who practices the four divine abidings will be reborn in the Brahmā world (brahma-loka) and will enjoy Brahmā's companionship. Prior to that, the meditator will enjoy several other benefits:

A man sleeps in comfort, wakes in comfort, and dreams no evil dreams, he is dear to human beings, he is dear to non-human beings, deities guard him, fire and poison and weapons do not affect him, his mind is easily concentrated, the expression of his face is serene, he dies unconfused. (IX.37)

The seven members of awakening are, naturally, qualities by virtue of which Nibbāna is attained, and if we look beyond the eudaimonistic states of early Buddhism, then the six perfections of the Bodhisattva are virtues which pave the path to Buddhahood.

Each of these practices is evaluated by standards of excellence defined by the community of practice. According to Buddhaghosa, among the measures for a cleansed

\footnotetext{
${ }^{11}$ Alternative explanations for the multiplicity of catalogs are possible. The variety we find may have resulted from a lack of theoretical ethical reflection on the part of Buddhist thinkers, which led to the absence of terminological and ideological uniformity (see Garfield 2008, par. 1-2; Keith 1923; $4^{\text {th }}$ edition 1963, 114; and Keown 2006, 46); alternatively, the classifications may have followed a different rationale, such as the analytical presentation of Buddhist teachings or philosophical ideas. My point is not that other considerations were not involved in the compilation of the lists that came down to usindeed, not all of the categories I mentioned have an equivalent eudaimonia - but rather that at least one concern reflected in this tendency is related to the eudaimonistic role of the virtues.
} 
sìla are the complete non-breaking of the training precepts, the absence of the "seven bonds of sexuality", the non-arising of negative states of mind, such as anger, envy, and pride, and the arising of positive qualities, such as fewness of wishes, contentment, and effacement (I.151). When the meditator excels in the practice of the four divine abidings, he should be able to break down the barriers between dear persons, neutral persons, hostile persons, and himself, and generate loving-kindness and so on towards all of them (IX.40, IX.81, IX.87, IX.89). Standards of excellence are also documented for the seven members of awakening. The sign of a cleansed concentration, for instance, is the "state partaking of distinction", which is defined as the state in which the meditator is "accessible to perception and attention unaccompanied by applied thought" (III.26). Despite the different notions of living well and standards of exellence, these practices share several key features that are outlined in MacIntyre's framework. The concepts of virtues that they employ are defined and explained by reference to the Buddhist understanding of suffering $(d u k k h a)$ and the telos of liberation from it. Similarly, this telos and the accompanied goods flow from a Buddhist narrative that encompasses its etiology of the human predicament, a given cosmological system, and a description of spiritual progress and soteriology.

What I wish to propose here is that we ought to take a broader view of Buddhist ethics which transcends the basic and rather intuitive equation of eudaimonia with Nibbāna (as proposed in Keown 1992 and Cooper and James 2005). Alongside the state of Nibbāna, the Buddhist tradition accepts other types of eudaimonia, such as rebirth in Brahmā world and a life of sìla, which are the good that ensues from a plurality of practices. This acceptance does not mean that all practices and types of living well are equal or that there is no hierarchy of values within them. Buddhaghosa clearly indicates that such a hierarchy exists. ${ }^{12}$ For instance, he evaluates Nibbāna as superior to sīla when he writes: "But once his virtue $[$ silla] is perfected, / His mind then seeks no other kind / Than the perfection of Nibbāna, / The state where utter peace prevails" (I.159). Although the virtuous life connected with the practice of silla is fortunate and successful, it is still beset by suffering. Therefore, Nibbāna is more desirable. For similar reasons, Nibbāna is also evaluated higher than life in the Brahmā world, which results from the practice of divine abidings. When Buddhaghosa enumerates the benefits of cultivating the four virtues of divine abidings, he concludes with the final advantage for the meditator, saying that "if he penetrates no higher, he will be reborn in the Brahmāworld" (IX.37). He then elucidates the last point: "If he penetrates no higher: if he is unable to reach higher than the attainment of loving-kindness and attain Arahantship, then when he falls from this life, he reappears in the Brahmā-world as one who wakes up from sleep" (IX.76). That is to say, for Buddhaghosa, Arahantship, the state of those who attain Nibbāna, is also superior to the wellbeing experienced in the Brahmā world.

The kind of acceptance exemplified in this version of virtue ethics, then, does not consider all practices and modalities of living well to be equal. Rather, it reflects the

\footnotetext{
12 This hierarchy is to be distinguished from a hierarchy of means to ends. By definition, these eudaimonias are all complete ends for the practitioner when he pursues one of them according to his level of spiritual development and motivation.
} 
same pluralistic spirit that Buddhism displays towards people with different capacities, who are situated in different places along the spiritual path, when it admits a variety of practices and philosophical views according to their level of spiritual maturity. Adopting this pluralistic spirit, different people may benefit from participating in different practices and from working towards the realization of different visions of living well that are suited to their inclinations and capacities. Therefore, the multiplicity of catalogs of moral virtues in Buddhism testifies to a theory that is both pluralisticacknowledging multiple legitimate practices, conceptions of eudaimonia, and moral characters - and gradualist, evaluating the variety of practices, eudaimonias, and moral characters according to a scale of spiritual freedom and peace.

\section{ACKNOWLEDGEMENTS}

I am grateful to the Robert H. N. Ho Family Foundation and American Council of Learned Societies for their generous support and to Keren Arbel, Udi Bauman, Shlomo Biderman, Vered Lamm-Naon, Joseph Loss, Christof Spitz, and an anonymous reviewer for insightful comments and suggestions on earlier versions of this paper.

\section{REFERENCES}

Annas, Julia (1993), The Morality of Happiness (Oxford: Oxford University Press). $<$ https://doi.org/10.1093/0195096525.001.0001>

Annas, Julia (2006), "Virtue Ethics", in David Copp (ed.), The Oxford Handbook of Ethical Theory (New York: Oxford University Press), 515-36. <https://doi. org/10.1093/oxfordhb/9780195325911.003.0019>

Aristotle, Nicomachean Ethics, ed. and trans. Roger Crisp (2000), Aristotle: Nicomachean Ethics (Cambridge: Cambridge University Press). <https://doi. org/10.1017/cbo9780511802058>

Asanga and Tsong-kha-pa Blo-bzan-grags-pa (1986), Asanga's Chapter on Ethics: With the Commentary of Tsong-Kha-Pa, The Basic Path to Awakening, The Complete Bodhisattva, trans. Mark Tatz (Lewiston, NY: Edwin Mellen Press).

Bodhi, Bhikkhu (2005), In the Buddha's Words: An Anthology of Discourses from the Pāli Canon (Somerville, MA: Wisdom Publications).

Buddhaghosa, Visuddhimagga, trans. Bhikkhu Ñāṇamoli (1956; 4 ${ }^{\text {th }}$ edition 2010), Visuddhimagga: The Path of Purification (Kandy, Sri Lanka: Buddhist Publication Society).

Clayton, Barbra R. (2006), Moral Theory in Śāntideva's Śikșāsamuccaya: Cultivating the Fruits of Virtue (London: Routledge). <https://doi.org/10.4324/9780203 639962>

Collins, Steven (1998), Nirvana and Other Buddhist Felicities: Utopias of the Pali Imaginaire (Cambridge: Cambridge University Press). < https://doi.org/10.1017 /cbo9780511520655> 
Cooper, David E., and James, Simon P. (2005), Buddhism, Virtue and Environment (Aldershot: Ashgate). <https://doi.org/10.4324/9781315261195>

Edelglass, William (2006), "Moral Pluralism, Skillful Means, and Environmental Ethics", Environmental Philosophy 3.2: 8-16. <https://doi.org/10.5840/enviro phil20063213>

Fink, Charles K. (2013), "The Cultivation of Virtue in Buddhist Ethics", Journal of Buddhist Ethics 20: 667-701.

Foot, Philippa (1978), "Virtues and Vices", in Philippa Foot, Virtues and Vices and Other Essays in Moral Philosophy (Berkeley: University of California Press), 118. <https://doi.org/10.1093/0199252866.003.0001>

Frazer, Michael L., and Slote, Michael (2015), "Sentimentalist Virtue Ethics", in Lorraine Besser-Jones and Michael Slote (eds), The Routledge Companion to Virtue Ethics (New York: Routledge), 197-207. < https://doi.org/10.4324 /9780203071755>

Garfield, Jay L. (2008), "Buddhist Ethics", paper presented at the XVth congress of the International Association of Buddhist Studies, Atlanta, Georgia, June 23-28, 2008. [Unpublished item.]

Gethin, Rupert (1992; reprint 2001), The Buddhist Path to Awakening: A Study of the Bodhi-Pakkhiyā Dhammā (Oxford: Oneworld Publications).

Gethin, Rupert (2004), "He Who Sees Dhamma Sees Dhammas: Dhamma in Early Buddhism", Journal of Indian Philosophy 32.5-6: 513-42. < https://doi.org /10.1007/s10781-004-8633-6>

Harvey, Peter (2000), An Introduction to Buddhist Ethics (Cambridge: Cambridge University Press). <https://doi.org/10.1017/cbo9780511800801>

Heim, Maria (2013), The Forerunner of All Things: Buddhaghosa on Mind, Intention, and Agency (Oxford: Oxford University Press). <https://doi.org/10.1093/ acprof:oso/9780199331031.001.0001>

Heim, Maria (2014), "Buddhaghosa on the Phenomenology of Love and Compassion", in Jonardon Ganeri (ed.), The Oxford Handbook of Indian Philosophy (New York, Oxford University Press), 171-89. < https://doi.org/10.1093/oxfordhb/9780199 314621.013.14>

Heim, Maria (2020), Buddhist Ethics (Cambridge: Cambridge University Press). $<$ https://doi.org/10.1017/9781108588270>

Keith, Arthur Berriedale (1923; $4^{\text {th }}$ edition 1963). Buddhist Philosophy in India and Ceylon (Varanasi: Chowkhamba Sanskrit Series Office).

Keown, Damien (1992), The Nature of Buddhist Ethics (Basingstoke: Macmillan). $<$ https://doi.org/10.1007/978-1-349-22092-2>

Keown, Damien (2006), "Buddhism: Morality without Ethics?", in Damien Keown (ed.), Buddhist Studies from India to America: Essays in Honor of Charles S. Prebish (London: Routledge), 40-8. <https://doi.org/10.4324/9780203098745>

MacIntyre, Alasdair (1981; $3^{\text {rd }}$ edition 2007), After Virtue: A Study in Moral Theory (Notre Dame, IN: University of Notre Dame Press). 
MacKenzie, Matthew (2018a), "Buddhism and the Virtues", in Nancy E. Show (ed.), The Oxford Handbook of Virtue (New York: Oxford University Press), 153-70. $<$ https://doi.org/10.1093/oxfordhb/9780199385195.013.18>

MacKenzie, Matthew (2018b), "Virtue, Self-Transcendence, and Liberation in Yoga and Buddhism", in Jennifer A. Frey and Candance Vogler (eds), SelfTranscendence and Virtue: Perspectives from Philosophy, Psychology, and Theology (New York: Routledge), 203-21. <https://doi.org/10.4324 /9780429469572>

McRae, Emily (2013), "Equanimity and Intimacy: A Buddhist-Feminist Approach to the Elimination of Bias", Sophia 52.3: 447-62. <https://doi.org/10.1007 /s11841-013-0376-y>

McRae, Emily (2016), "Equanimity and the Moral Virtue of Open-Mindedness", American Philosophical Quarterly 53.1: 97-108.

McRae, Emily (2017), "Equanimity in Relationship: Responding to Moral Ugliness", in Jake H. Davis (ed.), A Mirror Is for Reflection: Understanding Buddhist Ethics (Oxford: Oxford University Press), 336-52. <https://doi.org /10.1093/oso/9780190499778.003.0018>

Noddings, Nel (2015), "Care Ethics and Virtue Ethics", in Lorraine Besser-Jones and Michael Slote (eds), The Routledge Companion to Virtue Ethics (New York: Routledge), 401-14. <https://doi.org/10.4324/9780203071755>

Sahni, Pragati (2007), Environmental Ethics in Buddhism: A Virtues Approach (London: Routledge). <https://doi.org/10.4324/9780203946961>

Sāntideva (2016), The Training Anthology of Śāntideva: A Translation of the Śikșāsamuccaya, trans. Charles Goodman (New York: Oxford University Press).

Slote, Michael (2001), Morals from Motives (Oxford: Oxford University Press). $<$ https://doi.org/10.1093/0195138376.001.0001>

Swanton, Christine (2003), Virtue Ethics: A Pluralistic View (Oxford: Oxford University Press). <https://doi.org/10.1093/0199253889.001.0001>

Swanton, Christine (2015), "Pluralistic Virtue Ethics", in Lorraine Besser-Jones and Michael Slote (eds), The Routledge Companion to Virtue Ethics (New York: Routledge), 209-21.<https://doi.org/10.4324/9780203071755>

Tachibana, Shundo (1926; reprint 1987), The Ethics of Buddhism (New Delhi: Cosmo Publications).

Van Zyl, Liezl (2015), "Eudaimonistic Virtue Ethics", in Lorraine Besser-Jones and Michael Slote (eds), The Routledge Companion to Virtue Ethics (New York: Routledge), 183-95. <https://doi.org/10.4324/9780203071755>

Vasen, Meynard (2014), "Buddhist Practice as Play: A Virtue Ethical View", Journal of Buddhist Ethics 21: 537-68.

Vasen, Meynard (2018), "Buddhist Ethics Compared to Western Ethics", in Daniel Cozort and James Mark Shields (eds), The Oxford Handbook of Buddhist Ethics (Oxford: Oxford University Press), 317-33. <https://doi.org/10.1093/oxfordhb /9780198746140.013.30> 